\title{
Determining Constructions Phase Risk Mitigation of Shutdown Valve Control Panel Replacement Project West Madura Offshore
}

\author{
Shoffan Abdi Tunggal ${ }^{1}$, and Ervina Ahyudanari ${ }^{2}$ \\ ${ }^{1}$ Department of Technology Management, Institut Teknologi Sepuluh Nopember, Surabaya \\ ${ }^{2}$ Department of Civil Engineering, Institut Teknologi Sepuluh Nopember, Surabaya \\ e-mail: ervinaa.ariatedja@gmail.com
}

\begin{abstract}
Abstrak-PHA is an oil and gas Cooperation Contract Contractor (KKKS) in Indonesia, playing an important role in achieving the national oil and gas production target. To maintain operational and production continuity, a replacements shutdown valve control panel project performs at the production facility of West Madura offshore field. It was the first control panel replacement project carried out at the live production facility. Project team identify some high risk activity through process and occupational safety. Research needs in order to determine construction phase project risk mitigation, by hazard identification, risk analysis, classification and proposed preventive actions as necessary. Proposed analysis and risk management determined by Focus Group Discussion and House of Risk modeling methods, research identified 23 risk events, 23 risk agents, risk mitigation defined by aggregate risk potential and its prioritie. Aiming on reducing risk occurrence and improving positive impact for sustainability and objectives of the project. 24 preventive actions are selected with 5 top priority preventive action proposed.
\end{abstract}

Keywords-Risk Mitigation, Risk Register, House Of Risk, Shutdown Valve, Oil And Gas Industry.

\section{INTRODUCTION}

$\mathrm{P}$ HA is an oil and gas Cooperation Contract Contractor (KKKS) in Indonesia, playing an important role in achieving the national oil and gas production target. To maintain production continuity, a replacements shutdown valve control panel project performs at the production facility of West Madura Offshore field. It was the first high risk project performed at live plan.

Project aiming new level of proces safety facility with new control system by installaing new control panel. New control panel has additional capabilities to perform required partial test to ensure the integrity of SDV [1-2]. The working procedure of the project in construction phase needs to pay attention at important factors related with parameters of energy-based hazard properties processes such as pressure, temperature, mechanical, motion, gravity that impact the safety of people and processes [3-4]. SDV Schematic Panel With Partial Stroke Testing Fitur can see Figure 1.

PHA has risk management system adapted from SNI ISO 31000:2018 [5]. PHA risk management system called "Risk Management", one of the tools of Risk management is Risk Register. Risk Register used to identify and analyze risks, user friendly and simple. This tools has ability to analyze risk agent, risk event also preventive action directly by focus group discussion, the risk matrix used as variable to identify level of severity and probabiity of risk. Risk matrix defined by company standard.

Working step and procedure defined by ensure no shutdown facility during work is required, furthermore construction team shall update risk register. At this point previous risk register from another project which has similarity scheme also used as reference for updating risk register.

Study will determine risk mitigation by blending between Risk Register by risk management, with combination of brainstoming techique and house of risk modeling approach which has correlational relationship analysis. Previous study in this specific field are limited, and Hypothesis from earlier data using different method such as ANP, AHP and Pair Wise Comparison [6-8]. Otherwise another literature also study in different project phase [9],[6].

Furthermore, the propose proactive strategy of risk mitigation will defined in order to reduce the risk potensial during construction phase base on approval of propose study result [10-11].

\section{A. Valve}

Valve is a device or natural object with one or more function such as regulates, directs or controls the flow of a by opening, closing, or partially obstructing various passageways [1]. Valves are technically fittings, In an open valve, fluid flows in a direction from higher pressure to lower pressure. The word is derived from the Latin valva, the moving part of a door, in turn from volvere, to turn, roll.

A shutdown valve (SDV) is an actuated valve specialize designed to stop the flow of a hazardous fluid upon the detection of a dangerous event [1]. This provides protection against possible harm to people, equipment or the environment. Shutdown valves form part of a safety instrumented system [12]. The process of providing automated safety protection upon the detection of a hazardous event is called functional safety [13]

\section{B. Hazard}

Hazards as a source, situation or action that could potentially harm workers or cause illness or a combination of both [14]. Hierarchy of control are elimination, substitution, engineering control, administrative control and Personnel protective devices.[4][15][16]. 
The $6^{\text {th }}$ International Seminar on Science and Technology (ISST) 2020

July $25^{\text {th }}, 2020$, Institut Teknologi Sepuluh Nopember, Surabaya, Indonesia

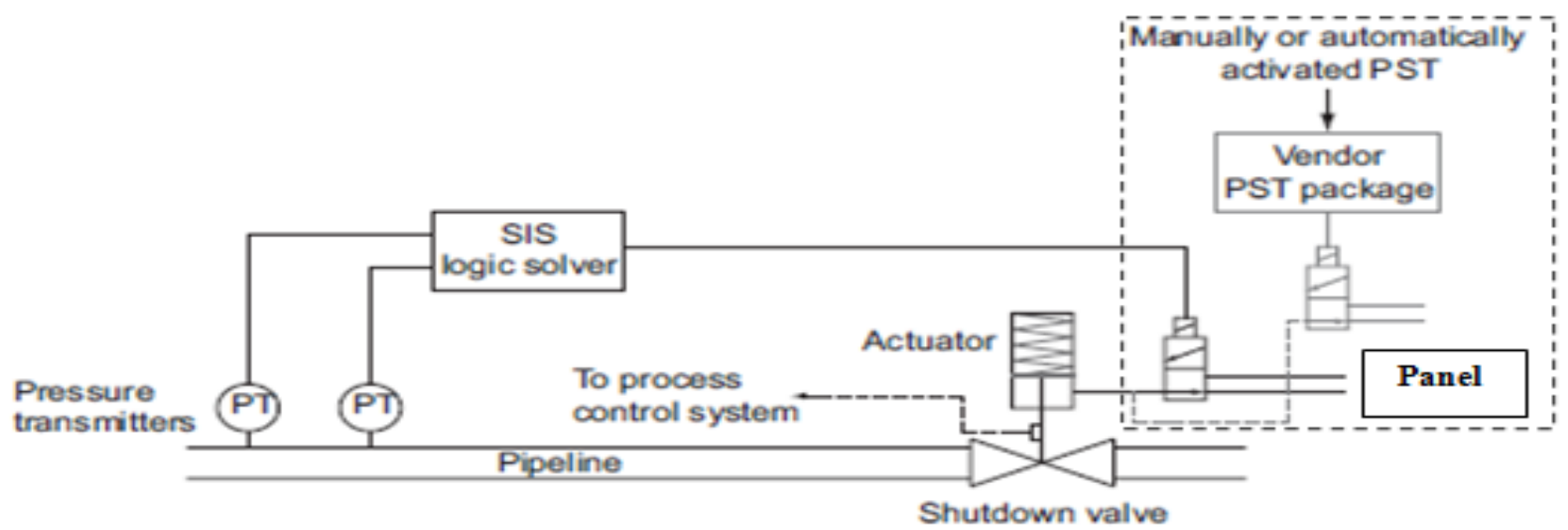

Figure 1. SDV Schematic Panel with Partial Stroke Testing Fitur.

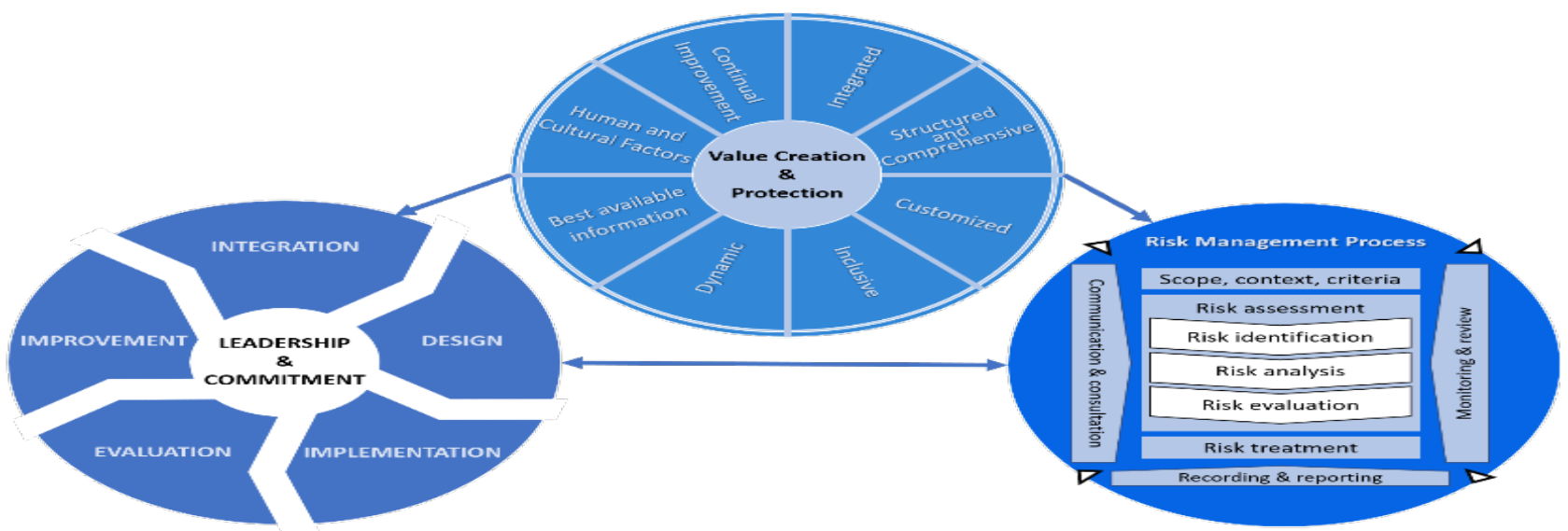

Figure 2. SNI ISO31000:2018 Principle, Framework and risk Management Process.

The biggest contributor to the cause of occupational accident is derived from the human negligence factor of $88 \%$ [17][12]. While the other $10 \%$ is from the unworthiness factor of property/assets/goods and $2 \%$ other factors.

Otherwise accidents occurred due to errors in the management of the system, in addition to the relationship between the number of events reporting almost woe and the number of major accidents that make it much easier from the accident can be predicted and avoided with a more comprehensive approach.

\section{Risk Management}

Risk management is all series of activities related to the risk of planning (planning), assessment, handling and risk monitoring [18][15]. Risk is a danger or consequence occurs from an ongoing process or an upcoming event.

There are five basic steps that are taken to manage risk[11]; these steps are referred to as the risk management process. It begins with identifying risks, goes on to analyze risks, then the risk is prioritized, a solution is implemented, and finally, the risk is monitored.

Risks are closely related to uncertainty and events, event, probability and impact of consequence are 3 main elements of risk. PHA risk management system adopt SNI ISO 31000:2018, Principles, frameworks and risk management processes according to SNI ISO 31000:2018 illustrated, and can see Figure 2.

\section{METHODOLOGY}

Study divided into 6 stages, which start with defining context, literature study, risk identification, risk analysis, risk evaluation, risk response and proposed preventive action. Data gathering by exploring previous another similar project data, manual document collecting, site direct observation, interview, and Forum Group Discussion (FGD).

\section{A. Focus Group Discussion}

FGD by gathering people from similar backgrounds or experiences to discuss a specific topic of interest. The group of participants is guided by a moderator (or group facilitator) who introduces topics for discussion and helps the group to participate in a lively and natural discussion amongst themselves. FGD held twice to accommodate effectiveness of discussion, because during FGD we need to review data from previous FEED study, Detail Engineering and lesson learn data from another project which has similar type.

\section{B. House of Risk (HOR)}

House of Risk is a model based on the need for risk management focused on preventive measures to determine which risk causes are priorities that would then be given the mitigation or risk-to-action), it use combination of House of 
The $6^{\text {th }}$ International Seminar on Science and Technology (ISST) 2020

July $25^{\text {th }}, 2020$, Institut Teknologi Sepuluh Nopember, Surabaya, Indonesia

\begin{tabular}{|c|c|c|c|c|c|c|c|c|c|c|c|c|c|c|c|c|c|c|c|c|c|c|c|c|}
\hline Risk Event (Ei) & & & & & & & & & & & & Risk & gent ( & & & & & & & & & & & $\begin{array}{c}\text { Severity of } \\
\text { Risk Event } \\
\text { i(Si) }\end{array}$ \\
\hline & A1 & A2 & A3 & A4 & A5 & A6 & A7 & A8 & A9 & $\mathbf{A 1 0}$ & A11 & A12 & A13 & A14 & A15 & A16 & A17 & A18 & A19 & $\mathbf{A 2 0}$ & A21 & A22 & $\mathrm{A23}$ & \\
\hline E1 & 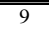 & 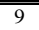 & 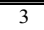 & 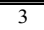 & 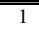 & & & & 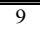 & 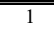 & 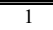 & $\begin{array}{c}3 \\
\end{array}$ & 83 & 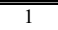 & 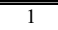 & 83 & $\begin{array}{c}3 \\
\end{array}$ & & $\begin{array}{c}3 \\
\end{array}$ & & & " & & 4 \\
\hline E2 & 9 & 3 & 1 & 1 & 3 & & & & 3 & 1 & 1 & 3 & 3 & 1 & 1 & 1 & 1 & & 3 & & 1 & 3 & & 4 \\
\hline E3 & 9 & 1 & & 3 & & & & 1 & 1 & 3 & 1 & 1 & 3 & & & 1 & 1 & & 1 & & 1 & 3 & & 3 \\
\hline E4 & 9 & 3 & 1 & 3 & 3 & 1 & 1 & 3 & 1 & 2 & 1 & 1 & 3 & & & 1 & 1 & & 3 & & 1 & 3 & & 2 \\
\hline E5 & 9 & 3 & 3 & 3 & 3 & 1 & 1 & 1 & 1 & 1 & 1 & 1 & 1 & 3 & & 9 & & & 1 & & & 1 & & 2 \\
\hline E6 & 3 & 1 & 1 & 1 & 3 & 9 & 3 & 3 & 3 & 9 & 1 & 1 & & & & & & 3 & 3 & 3 & 1 & 3 & & 3 \\
\hline E7 & 3 & 1 & & 1 & 1 & & 3 & 3 & 9 & 3 & & 3 & 3 & 3 & 1 & 3 & & & & & 1 & 3 & & 2 \\
\hline E8 & 1 & 1 & & & 2 & & 1 & & 3 & & & 1 & 3 & 3 & 1 & 1 & & & 1 & & 1 & 3 & & 3 \\
\hline E9 & 9 & 3 & & & 3 & & & & 3 & & 3 & 3 & 3 & & & 1 & & & 1 & & & 1 & & 4 \\
\hline E10 & 9 & 3 & & & 1 & & & & 3 & & & 1 & 1 & 1 & & 3 & 3 & 1 & 1 & & 1 & 1 & & 2 \\
\hline E11 & 3 & 1 & & 1 & 3 & 9 & 1 & 3 & 3 & 3 & & & & & & & & 1 & 9 & & 1 & 3 & & 2 \\
\hline E12 & & & & & 3 & & & & & & & & & & & & & & 9 & 3 & 3 & 1 & & 3 \\
\hline E13 & 9 & 3 & & & 3 & & 3 & 9 & & & 3 & 3 & & & 3 & 3 & 3 & 1 & 3 & 3 & & 1 & & 3 \\
\hline E14 & 3 & 3 & & 1 & 9 & 9 & 1 & 3 & 1 & 9 & & 3 & & & & 1 & 1 & 3 & 9 & & & & 9 & 4 \\
\hline E15 & 1 & 1 & 1 & 1 & 1 & 1 & 1 & 9 & & 3 & & & & & & & & & 3 & & & & 9 & 3 \\
\hline E16 & 9 & 1 & & & 1 & 1 & & & & & 9 & 9 & & & 3 & 1 & 1 & & 3 & & 3 & 1 & & 3 \\
\hline E17 & 9 & 3 & & & 1 & 1 & & & & & 3 & 9 & & & 3 & 1 & 1 & & 3 & & & 1 & & 3 \\
\hline E18 & 1 & 9 & 1 & 3 & 9 & 9 & 1 & 3 & & 3 & & & & 1 & & & & & 1 & & & 1 & & 2 \\
\hline E19 & 1 & 1 & 1 & 1 & 1 & 1 & & & 3 & & & & 1 & & & & 1 & & 3 & & & & & 2 \\
\hline E20 & 1 & & & & & & 9 & & & & & 3 & & & 1 & 1 & & & 1 & 1 & 1 & 1 & & 3 \\
\hline E21 & & & & & 1 & & & & 1 & 1 & & & 1 & 1 & & & & & 1 & & & & & 3 \\
\hline E22 & 1 & 3 & & & 3 & & 1 & 1 & & & & & 3 & & & & 1 & & 3 & 9 & 1 & 1 & & 3 \\
\hline E23 & & & & & & & & & & 1 & & & 1 & & & & & & 9 & & & & & 2 \\
\hline $\begin{array}{c}\text { Occurance of } \\
\text { Agent } j\end{array}$ & 4 & 3 & 2 & 3 & 2 & 3 & 2 & 2 & 2 & 2 & 1 & 3 & 3 & 2 & 2 & 2 & 2 & 2 & 2 & 2 & 2 & 1 & 2 & \\
\hline
\end{tabular}

Figure 3. Risk Event, Risk Agent, Severity and Occurrence Index (FGD1).

\begin{tabular}{|c|c|c|c|c|c|c|c|c|c|c|c|c|c|c|c|c|c|c|c|c|c|c|c|c|}
\hline Risk Event (Fi) & & & & & & & & & & & & Risk & gent ( & & & & & & & & & & & $\begin{array}{c}\text { Severity of } \\
\text { Risk Event } \\
\text { i(Si) }\end{array}$ \\
\hline & A1 & $\mathbf{A 2}$ & $\mathbf{A 3}$ & $\mathbf{A 4}$ & A5 & A6 & $\mathbf{A 7}$ & A8 & A9 & $\mathbf{A 1 0}$ & $\mathbf{A 1 1}$ & $\mathbf{A 1 2}$ & $\mathbf{A 1 3}$ & $\mathbf{A 1 4}$ & $\mathbf{A 1 5}$ & A16 & $\mathbf{A 1 7}$ & $\mathbf{A 1 8}$ & $\mathbf{A 1 9}$ & $\mathbf{A 2 0}$ & $\mathbf{A 2 1}$ & $\mathbf{A 2 2}$ & $\mathbf{A 2 3}$ & \\
\hline E1 & 36 & 36 & 12 & 12 & 4 & & & & 36 & 4 & 4 & 12 & 12 & 4 & 4 & 12 & 12 & & 12 & & & 12 & & 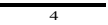 \\
\hline E2 & 36 & 12 & 4 & 4 & 12 & & & & 12 & 4 & 4 & 12 & 12 & 4 & 4 & 4 & 4 & & 12 & & 4 & 12 & & 4 \\
\hline $\mathrm{E} 3$ & 27 & 4 & & 12 & & & & 4 & 4 & 12 & 4 & 4 & 12 & & & 4 & 4 & & 4 & & 4 & 12 & & 3 \\
\hline E4 & 18 & 12 & 4 & 12 & 12 & 4 & 4 & 12 & 4 & 8 & 4 & 4 & 12 & & & 4 & 4 & & 12 & & 4 & 12 & & 2 \\
\hline E5 & 18 & 12 & 12 & 12 & 12 & 4 & 4 & 4 & 4 & 4 & 4 & 4 & 4 & 12 & & 36 & & & 4 & & & 4 & & 2 \\
\hline E6 & 9 & 4 & 4 & 4 & 12 & 36 & 12 & 12 & 12 & 36 & 4 & 4 & & & & & & 12 & 12 & 12 & 4 & 12 & & 3 \\
\hline E7 & 6 & 4 & & 4 & 4 & & 12 & 12 & 36 & 12 & & 12 & 12 & 12 & 4 & 12 & & & & & 4 & 12 & & 2 \\
\hline E8 & 3 & 4 & & & 8 & & 4 & & 12 & & & 4 & 12 & 12 & 4 & 4 & & & 4 & & 4 & 12 & & 3 \\
\hline E9 & 36 & 12 & & & 12 & & & & 12 & & 12 & 12 & 12 & & & 4 & & & 4 & & & 4 & & 4 \\
\hline E10 & 18 & 12 & & & 4 & & & & 12 & & & 4 & 4 & 4 & & 12 & 12 & 4 & $\begin{array}{l}4 \\
4\end{array}$ & & 4 & 4 & & 2 \\
\hline $\begin{array}{l}\text { E10 } \\
\text { El }\end{array}$ & 6 & 4 & & 4 & 12 & 36 & 4 & 12 & 12 & 12 & & & & & & & & 4 & 36 & & 4 & 12 & & 2 \\
\hline E12 & & & & & 12 & & & & & & & & & & & & & & 36 & 12 & 12 & 4 & & 3 \\
\hline E13 & 27 & 12 & & & 12 & & 12 & 36 & & & 12 & 12 & & & 12 & 12 & 12 & 4 & 12 & 12 & & 4 & & 3 \\
\hline E14 & 12 & 12 & & 4 & 36 & 36 & 4 & 12 & 4 & 36 & & 12 & & & & 4 & 4 & 12 & 36 & & & & 36 & 4 \\
\hline E15 & 3 & 4 & 4 & 4 & 4 & 4 & 4 & 36 & & 12 & & & & & & & & & 12 & & & & 36 & 3 \\
\hline E16 & 27 & 4 & & & 4 & 4 & & & & & 36 & 36 & & & 12 & 4 & 4 & & 12 & & 12 & 4 & & 3 \\
\hline E17 & 27 & 12 & & & 4 & 4 & & & & & 12 & 36 & & & 12 & 4 & 4 & & 12 & & & 4 & & 3 \\
\hline E18 & 2 & 36 & 4 & 12 & 36 & 36 & 4 & 12 & & 12 & & & & 4 & & & & & 4 & & & 4 & & 2 \\
\hline E19 & 2 & 4 & 4 & 4 & 4 & 4 & & & 12 & & & & 4 & & & & 4 & & 12 & & & & & 2 \\
\hline E20 & 3 & & & & 4 & & 36 & & 12 & & & 12 & 4 & & 4 & 4 & & & 4 & 4 & 4 & 4 & & 3 \\
\hline E21 & & & & & 4 & & & & 4 & & & & 4 & 4 & & & & & $\begin{array}{l}4 \\
4\end{array}$ & 4 & 4 & 4 & & 3 \\
\hline E22 & 3 & 12 & & & 12 & & 4 & 4 & & & & & 12 & & & & 4 & & 12 & 36 & 4 & 4 & & 3 \\
\hline $\mathrm{E} 23$ & & & & & & & & & & 4 & & & 4 & & & & & & 36 & & & & & 2 \\
\hline $\begin{array}{c}\text { Occurance of } \\
\text { Agent } j\end{array}$ & 4 & 3 & 2 & 3 & 2 & 3 & 2 & 2 & 2 & 2 & 1 & 3 & 3 & 2 & 2 & 2 & 2 & 2 & 2 & 2 & 2 & 1 & 2 & \\
\hline $\begin{array}{c}\text { Aggregate risk } \\
\text { potential } \mathbf{j}\end{array}$ & 1276 & 636 & 96 & 264 & 440 & 504 & 208 & 312 & 352 & 320 & 96 & 540 & 348 & 112 & 112 & 240 & 136 & 72 & 592 & 152 & 128 & 136 & 144 & \\
\hline Priority rank of & 1 & 2 & 21 & 11 & 6 & 5 & 13 & 10 & 7 & 9 & 22 & 4 & 8 & 19 & 20 & 12 & 16 & 23 & 3 & 14 & 18 & 17 & 15 & \\
\hline
\end{tabular}

Figure 4. HOR 1 Result.

Quality (HOQ) model Approach with Failure Mode Effect Analysis (FMEA). HOR approach analysis uses combination or correlation and risk priority indexing, this approach as a key risk selection method and then put it in House of Quality.

FMEA is an analytical tool that can evaluate reliability by examining the failure mode and is one of the systematic techniques for analyzing failures. According to FMEA, risk assessment can be calculated through the calculation of RPN (Risk Potential Number) derived from the multiplication of three factors, namely the probability of occurrence of risk, impact of damage generated, and risk detection [13]. This method are commonly used at several study for investigating incident at oil and gas facility [12][16-17].

We use two deployment models, called HOR, both of which are based on the modified HOQ:n(1) HOR1 is used to determine which risk agents are to be given priority for preventive actions.(2) HOR2 is to give priority to those actions considered effective but with reasonable money and resource commitments.

In the HOQ model, a set of requirements (what) and a set of responses (how) where each response could address one or more requirements. The degree of correlation is typically classified as none (and given an equivalent value of 0 ), low (one), moderate (three), and high (nine). Each requirement has a certain gap to fill and each response would require some types of resources and funds.

HOR2 used to determine which actions are to be done first, considering their differing effectiveness as well as resources involved and the degree of difficulties in performing. The company should ideally select set of actions that are not so difficult to perform but could effectively reduce the probability of risk agents occurring.

\section{RESULT AND DISCUSSIONS}

FGD1 identify 23 risk agent and 23 Risk event that probably occurs during construction phase. Furthermore, team identified risk agent, risk event and correlation between them, not limited to severity and Occurrences value. Risk Event, Risk Agent, Severity and Occurrence Index (FGD1) and can see Figure 3. Figure 4 show the the result of the HOR1. Refer to value specified on FGD1, Figure 4 is result 
The $6^{\text {th }}$ International Seminar on Science and Technology (ISST) 2020

July $25^{\text {th }}, 2020$, Institut Teknologi Sepuluh Nopember, Surabaya, Indonesia

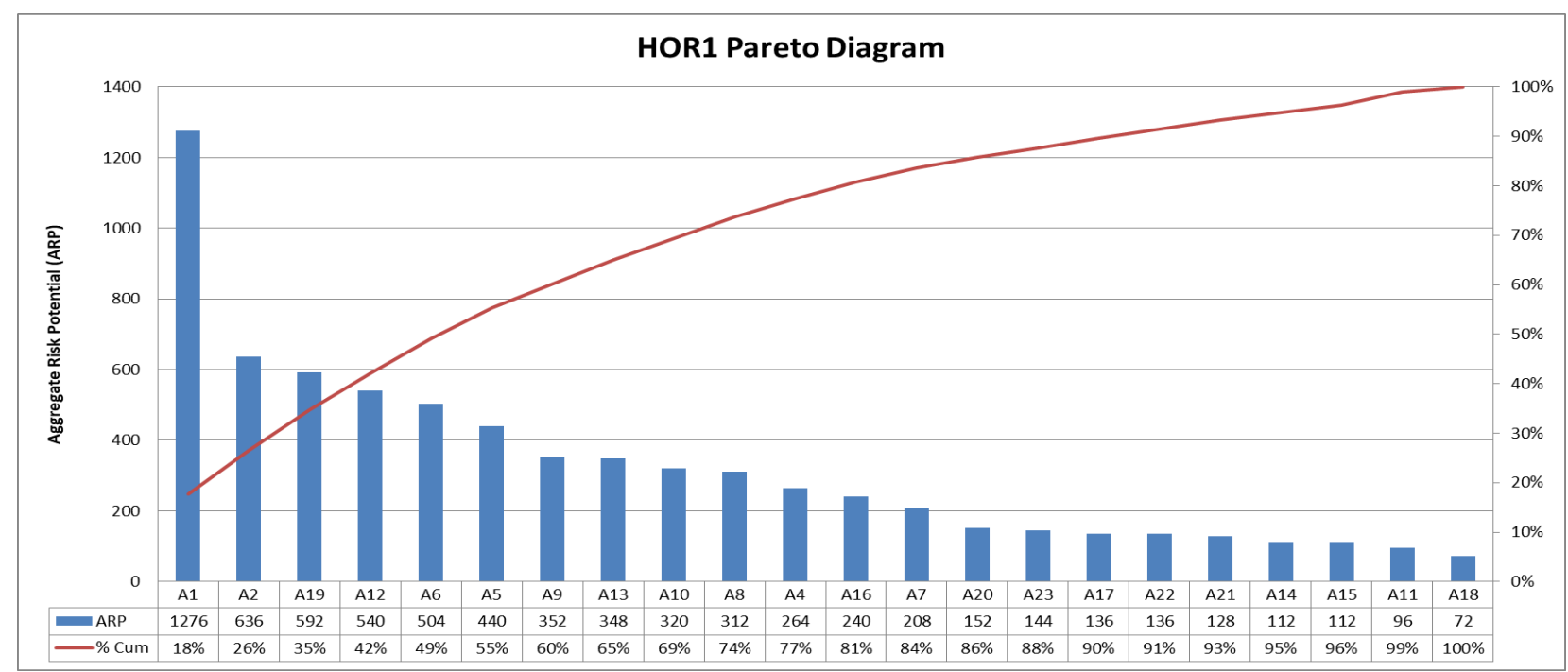

Figure 5. Pareto diagram of aggregate risk potentials of all risk agents.

\begin{tabular}{|c|c|c|c|c|c|c|c|c|c|c|c|c|c|c|c|c|c|c|c|c|c|c|c|c|c|}
\hline \multirow{2}{*}{ Risk Agent } & \multicolumn{24}{|c|}{ Preventive Action } & \multirow{2}{*}{ ARP } \\
\hline & PA1 & $\mathrm{PA} 2$ & PA3 & PA4 & PA5 & PA6 & PA7 & PA8 & PA9 & PA10 & PA11 & PA12 & PA13 & PA14 & PA15 & PA16 & PA17 & PA18 & PA19 & PA20 & PA21 & 1 PA22 & PA23 & 3 PA24 & \\
\hline $\mathrm{Al}$ & 15552 & 15552 & 5184 & & 5184 & 3456 & & & & & & & & 5184 & & & & & & & & & & 3456 & 1728 \\
\hline A2 & 1908 & 1908 & 636 & 1908 & 1908 & 1908 & & & 636 & 1908 & 5724 & & & 636 & 5724 & 636 & & & & 636 & & 636 & 1908 & 636 & 636 \\
\hline A19 & & & & & & & 1620 & 1620 & & & & & 540 & & & & & & & & & & & & 592 \\
\hline A 12 & & & & 504 & & & 504 & & 1512 & 1512 & 504 & 504 & 504 & & & & & & & & & & & & 540 \\
\hline A6 & & & 1320 & 1320 & 1320 & 1320 & 440 & & & & 1320 & 1320 & & & 440 & 440 & & & & & 440 & & & 440 & 504 \\
\hline A5 & & 352 & 352 & 1056 & 352 & 352 & 1056 & 352 & & 1056 & 1056 & 352 & 3168 & 1056 & 3168 & 352 & & & & & & & 352 & & 440 \\
\hline A9 & 352 & 348 & 348 & 348 & & & & & & & & & & 348 & 348 & 3132 & 1044 & & & & & & & & 352 \\
\hline $\mathrm{A} 13$ & 348 & 960 & & & & & & & & & 320 & 960 & & 960 & & & 320 & 2880 & 2880 & & & 320 & & & 348 \\
\hline $\mathrm{A} 10$ & 320 & 936 & 312 & & & & & & & & & 312 & & & & 312 & 312 & & & 936 & 312 & & & & 320 \\
\hline A8 & & & 264 & & & & & & & & & & & & & 264 & 264 & & & 264 & 2376 & 792 & & & 312 \\
\hline A4 & & & & & & 240 & & & & 240 & & & & & & & & & & & & & 2160 & 240 & 264 \\
\hline $\mathrm{A} 16$ & & & & & 240 & 240 & & & & 240 & 240 & & & & & & & & & & & 240 & & 2160 & 240 \\
\hline Tek & 18480 & 20056 & 8416 & 5136 & 9004 & 7516 & 3620 & 1972 & 2148 & 4956 & 9164 & 3448 & 4212 & 8184 & 9680 & 5136 & 1940 & 2880 & 2880 & 1836 & 3128 & 1988 & 4420 & 6932 & \\
\hline $\mathrm{Dk}$ & 2 & 2 & 3 & 3 & 2 & 2 & 2 & 2 & 2 & 2 & 2 & 2 & 2 & 3 & 2 & 2 & 1 & 2 & 2 & 3 & 3 & 2 & 2 & 2 & \\
\hline ETD & 9240 & 10028 & 2805 & 1712 & 4502 & 3758 & 1810 & 986 & 1074 & 2478 & 4582 & 1724 & 2106 & 2728 & 4840 & 2568 & 1940 & 1440 & 1440 & 612 & 1043 & 994 & 2210 & 3466 & \\
\hline Prio & 1 & 2 & 8 & 17 & 5 & 6 & 15 & 23 & 20 & 11 & 4 & 16 & 13 & 9 & 3 & 10 & 14 & 18 & 19 & 24 & 21 & 22 & 12 & 7 & \\
\hline
\end{tabular}

Figure 6. HOR2 Pareto Diagram Result.

of HOR1 modeling approach. Pareto diagram of aggregate risk potentials of all risk agents can see Figure 5.

Study prioritize top risk agent with ARP value from result of HOR1, and consider which risk agent prioritized. Regarding it, in order to Identify actions considered relevant for preventing the risk agents. 12 prioritized risk agent chooses on FGD2, It is possible that one risk agent could be prevented by one or more preventive action.

Afterward FGD2 choose 24 preventive action to tackle 12 prioritized risk agent chooses before. Preventive action criteria shall the easiest and most effective risk response, otherwise company regulation are strict on "Change Order" because of fiscal impact. It's important to avoid extensive time and additional costs, but it should meet with the agreement corridor of the contract.

Study prioritized 24 preventive action. priority for each action is obtained based on the values of the effectiveness to difficulty ratio of action $\mathrm{k}$ (ETD). The higher the ratio, the more cost effective is the proposed action.

Refer to figure 6 , the most effective action would be to reduce probability of incident during project construction phase. FGD2 defined top 5 Preventive action should propose to senior management in order to speed up approval for implementation, as study limited to only determine the construction phase risk mitigation at all.

\section{CONCLUSION}

Study defined 23 risk event and 23 risk agent. 12 prioritize risk agent chosen to analyze and evaluate to the next step by FGD1. As result of FGD1, study defined 24 preventive action, and define 5 prioritize preventive action based on effectiveness and difficulty level.

Since this study are limited only to determine risk mitigtion during project construction phase, project team has propose 5 chosen prioritize preventive action should proposed as second opinion to senior management for implementation approval. This kind of study gives managerial implication as additional second opinion for decision making.

We are suggest to continue study in similar type of project with another brainstorming technique, and modeling 
The $6^{\text {th }}$ International Seminar on Science and Technology (ISST) 2020

July $25^{\text {th }}, 2020$, Institut Teknologi Sepuluh Nopember, Surabaya, Indonesia

approach to enrich and explore more knowledge especially at similar project.

\section{REFERENCES}

[1] A. P. Institute, API STD 598: Valve Inspection \& Testing, 10th ed. United States: American Petroleum Institute (API), 2016.

[2] M. A. Lundteigen and M. Rausand, "Partial stroke testing of process shutdown valves: How to determine the test coverage," J. Loss Prev. Process Ind., vol. 21, no. 6, pp. 579-588, 2008, doi: 10.1016/j.jlp.2008.04.007.

[3] A. Albert, M. R. Hallowell, and B. M. Kleiner, "Enhancing construction hazard recognition and communication with energy-based cognitive mnemonics and safety meeting maturity model: multiple baseline Study," J. Constr. Eng. Manag., vol. 140, no. 2, p. 04013042 , 2014, doi: 10.1061/(asce)co.1943-7862.0000790.

[4] I. for O. S. and H. (NIOSH), "Hierarchy of Controls." Department of Health \& Human Services, United State, 2018.

[5] Badan Standardisasi Nasional, Manajemen Risiko - Prinsip dan Pedoman (ISO 31000:2009,IDT). Jakarta, Indonesia: Badan Standardisasi Nasional, 2016.

[6] C. W. Oktavia, "Analisis dan Mitigasi Resiko dengan Pendekatan Interpretetive Structural Modeling (ISM), Analytical Network Process (ANP), dan House of Risk (HOR) pada Proses Pengadaan Barang dan Jasa di PT. Semen Indonesia (Persero) Tbk," Institut Teknologi epuluh Nopember, Surabaya, 2005.

[7] R. Fitriana, "Kajian Risiko Keselamatan Kerja Pada Proses Overhaul Tangki Timbun L.3 di PT Pertamina (Persero) Refinery Unit III PlajuSungai Gerong-Palembang," Universitas Indonesia, Depok, Indonesia., 2012.

[8] D. Kurniasari, "Aplikasi Model House of Risk ( Hor ) Untuk Mitigasi
Risiko Proyek Pembangunan Jalan," in Prosiding Seminar Nasional Manajemen Teknologi XI, 2014, vol. 13, no. 2, pp. 1-10.

[9] A. Retna Maharani, "Perancangan Manajemen Risiko Operasional Di Pt . X Dengan Menggunakan Metode House of Risk," Institut Teknologi Sepuluh Nopember Surabaya, 2018.

[10] M. A. Mustafa and J. F. Al-Bahar, "Project Risk Assessment Using the Analytic Hierarchy Process," IEEE Trans. Eng. Manag., vol. 38, no. 1, pp. 46-52, 1991, doi: 10.1109/17.65759.

[11] I. P. A. Wiguna and S. Scott, "Nature Of The Critical Risk Factors Affecting Project Performance In Indonesian Building Contracts," in 21st Annual ARCOM Conference, 2005, pp. 225-235.

[12] O. J. Tveit, "Safety issues on offshore process installations. An overview," J. Loss Prev. Process Ind., vol. 7, no. 4, pp. 267-272, 1994, doi: 10.1016/0950-4230(94)80039-1.

[13] National Commission on the BP Deepwater Horizon Oil Spill and Offshore Drilling, Deep Water - The Gulf Oil Disaster and the Future of Offshore Drilling, vol. 30, no. 2. USA: National Commission on the BP Deepwater Horizon Oil Spill and Offshore Drilling, 2011.

[14] O. H. and S. Assessment, BS OHSAS 18001 (2018), Occupational Health and Safety Assessment. United Kingdom: International Organization for Standardization, 2018.

[15] Australian/New Zealand Standard, Risk Management AS/NZS 4360:2004, 2nd ed. Sydney and Wellington: Standards Autralia International Ltd and Standars New Zealand, 1999.

[16] Alberta Environment, Risk Management Guidelines for Petroleum Storage Tank Sites, no. October. Street Edmonton, Alberta: Science and Standards Division Alberta Environment, 2001.

[17] K. Miller, "An offshore gas field safety strategy and quantitative risk assessment model," J. Loss Prev. Process Ind., vol. 7, no. 4, pp. 331336, 1994, doi: 10.1016/0950-4230(94)80046-4.

[18] Standard, Australia, and License, Guidelines for Managing Risk: AS/NZS 4360. Australia: Standards Association of Australia, 1999. 